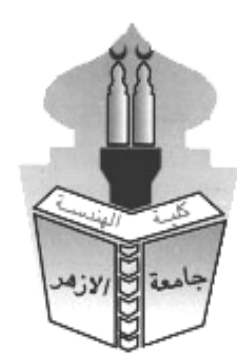

\title{
OPTIMIZATION OF BLENDING OPERATION FOR PHOSPHATE MINES AND STOCKPILES USING LINEAR PROGRAMMING TECHNIQUE IN MINING

\author{
Mostafa M. Elbeblawi ${ }^{1}$, Mahmoud M. Ahmed ${ }^{1}$, Solaiman S. Hassan ${ }^{2}$, Amr G. Ateto ${ }^{3}$ \\ ${ }^{1}$ Department of Mining and Metallurgical, Faculty of Engineering, Assiut University, Egypt. \\ ${ }^{2}$ Economics and Public Finance, Faculty of Commerce, Assiut University, Egypt. \\ ${ }^{3}$ Department of Mining and Metallurgical, Faculty of Engineering, Assiut University, Egypt
}

\begin{abstract}
Blending operation of different grades of ores is performed to maintain the rich part of ore as much as possible. The purpose of this paper is to find the optimum solution of blending operation of phosphate ore applying linear programming using Excel Solver Spreadsheet Software Packages. Optimization process was applied to three phosphate mines based on selling price as a control factor. The same mines were optimized in another way taking profit in the objective function of the blending process. The obtained results gave the same blending percentages with the two options. There is a big difference in the gained profit up to 18 million dollars when the selling price option was applied as a control factor. On the other hand, seven stockpiles of phosphate ore; each has quantity and average grade extracted and accumulated from different mines. The final profit calculated from the option of selling price as a control factor was 360 thousand dollars higher than the one estimated when profit control factor was used.
\end{abstract}

KEYWORDS: Optimization, phosphate; Linear programming; solver; blending; stockpiles.

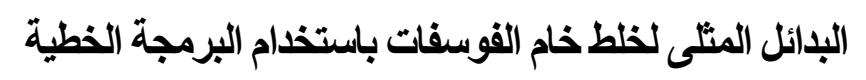

مصطفى محمد البيلاوي 1، محمود محمد احمد 1، سليمان سعيد حسن 2، عمرو جمال عطيتو 3

$$
2 \text { مدرس الاقتصاد و المالية العامة، كلية التجارة، جامعة أسيوط، ملية التهدسة، جامعة أسيوط، مصر }
$$


يتم إجر اء عملية خلط درجات مختلفة من الخامات للحفاظ على الجزء الغني من الخام قدر الإمكان. الغرض من هذا البحث هـ إئ إيجاد

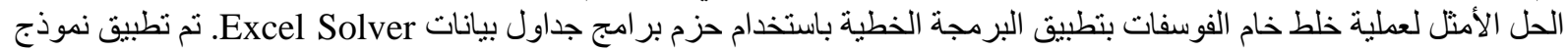

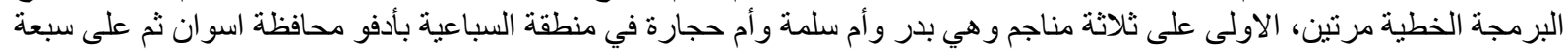

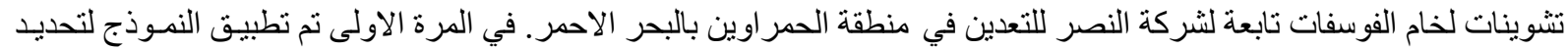

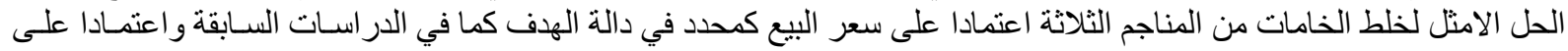

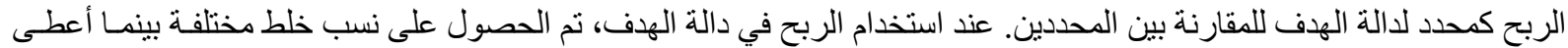

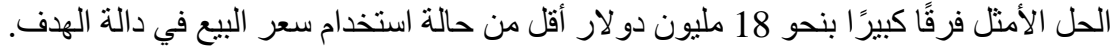
الكلمات المفتاحية: البدائل المثلى، الفوسفات؛ البرمجة الخطية؛ الخلط

\section{INTRODUCTION}

Optimization is the problem of obtaining the best solution out of all the feasible ones. The optimum alternative is most often the maximum or the minimum solution reliant on the problem. Ordinary applications are scheduling problems, blending problems or other problems with a lot of solutions [1]. Blending problems occurs whenever we must choose how to combine two or more materials to produce one or more products. These kinds of problems happen frequently in the mining industry, such as blending low grade ores with high grade to produce assays which are required for sale and these blended ores must satisfy requirements of all constraints of sales contracts or for the next step of ore treatment.[2]

A linear programming model was applied to iron ore deposits located in Brazil. The blending model predicted a reduction of variability of the grades of $\mathrm{SiO} 2$ feeding processing plant, depending on the pile size and number of layers selected. A geostatistical simulated grade model was used to reproduce the characteristics of the mineral deposit. The solution of this model leads to an appropriate pile and stock yard dimensions with a minimized $\mathrm{SiO} 2$ grade in the feed of the processing plant.[3]

The major components of constrained optimization model are objective function, decision variables and constraints. Objective function which defines the criterion for evaluating the alternative. It is a mathematical function of the decision variables that converts the solution into a numerical estimation of that alternative. Decision variables are physical quantities regulated by the decision maker and are represented by mathematical symbols. Constraints are functional equalities or inequalities that represent physical, economic, technical, ethical, legal, or other limitations on what numerical values can be appointed to the decision variables. The steps in problem formulation are as follows; identify and define the outcome variables for the problem, define the objective function, identify, and express mathematically all relevant constraints .[4]

In Egypt, the phosphate belt extends from the westward of the Dakhla oases to the Abu Tartur plateau, as well as, in the southeast of Al-Kharja oasis and then appears again in between Esna and Qena and then east through the Qena Valley until they appear on the Red Sea coast in the area confined between north of Safaga and even south of Qusseir through Hamrawein.[5,6]

Arindam Biswas et.al., presented an idea of Crop development and various algorithms which are used to solve crop planning optimization problem and focused on the problems that need effective solutions. Crop planning optimization is to develop the minimum resources to obtain the maximum profit by way of optimizing the objectives. They proposed a model to minimize the total personnel cost while maintaining other fertilizer constraints provided.[7]

Phosphate ore reserves in Egypt mentioned in the records of the United States geological survey, are about 1300 million tons [8,9]. In this work, three phosphate mines were studied. These mines are belonging to El-Nasr Mining Company in Sebaeya western area, Aswan governorate, Egypt located in the Nile Valley. These mines named Um Salamh, Hegara and Badr. They have reserves of 1565054.4ton, 2317830 ton, and 1488719.9 ton, respectively. Also, an optimization model was applied to seven stockpiles of phosphate ore located in Nasr mining company in Hamrawein, Qusseir, Red Sea governorate, Egypt. Figure 1 shows the map of the location of those mines belonging to Nasr Mining Company in Aswan governorate, Egypt [10].

Optimization model based on selling price as a control factor was applied to three phosphate mines named Salamh, Hegara and Badr. The model resulted that a specified quantity of phosphate ore with 


\section{OPTIMIZATION OF BLENDING OPERATION FOR PHOSPHATE MINES AND STOCKPILES USING LINEAR PROGRAMMING TECHNIQUE IN MINING}

grade $30 \%$ P2O5 is obtained by mixing $92.6 \%$ of the quantity from Salamh mine and $7.4 \%$ from Badr mine. For the grade $28 \% \mathrm{P}_{2} \mathrm{O}_{5}$, the required quantity is obtained by blending $11.8 \%$ of the quantity from Salamh mine, 54.9\% from Hegara mine and 33.3\% from Badr mine. The same mines were optimized in another way taking profit in the objective function of the blending process. The obtained results gave different blending percentages with the two options. There is a big difference in the gained profit up to 18 million dollars when the selling price option was applied as a control factor.

On the other hand, seven phosphate stockpiles belong to Nasr Mining Company in the Hamrawein area, Red Sea were optimized using selling price and profit in the objective function. The difference was about 360 thousand dollars between the two ways. In case of using selling price in the objective function, the results were summarized for some assays as follows; to obtain phosphate grade of $31 \%$ P2O5, 90\% of the quantity should be taken from stockpile No.1 and $10 \%$ from stockpile No.2. A required quantity of phosphate ore with grade of $27 \%$ P2O5 is obtained by mixing $46.5 \%$ of the quantity from stockpile No.4, 40\% from stockpile No.5, 9.5\% from stockpile No.6 and 4\% from stockpile No.7. To obtain a phosphate grade of $22 \%$ P2O5, $37.5 \%$ of the required quantity should be taken from stockpile No.4 and 62.5\% from stockpile No.7.

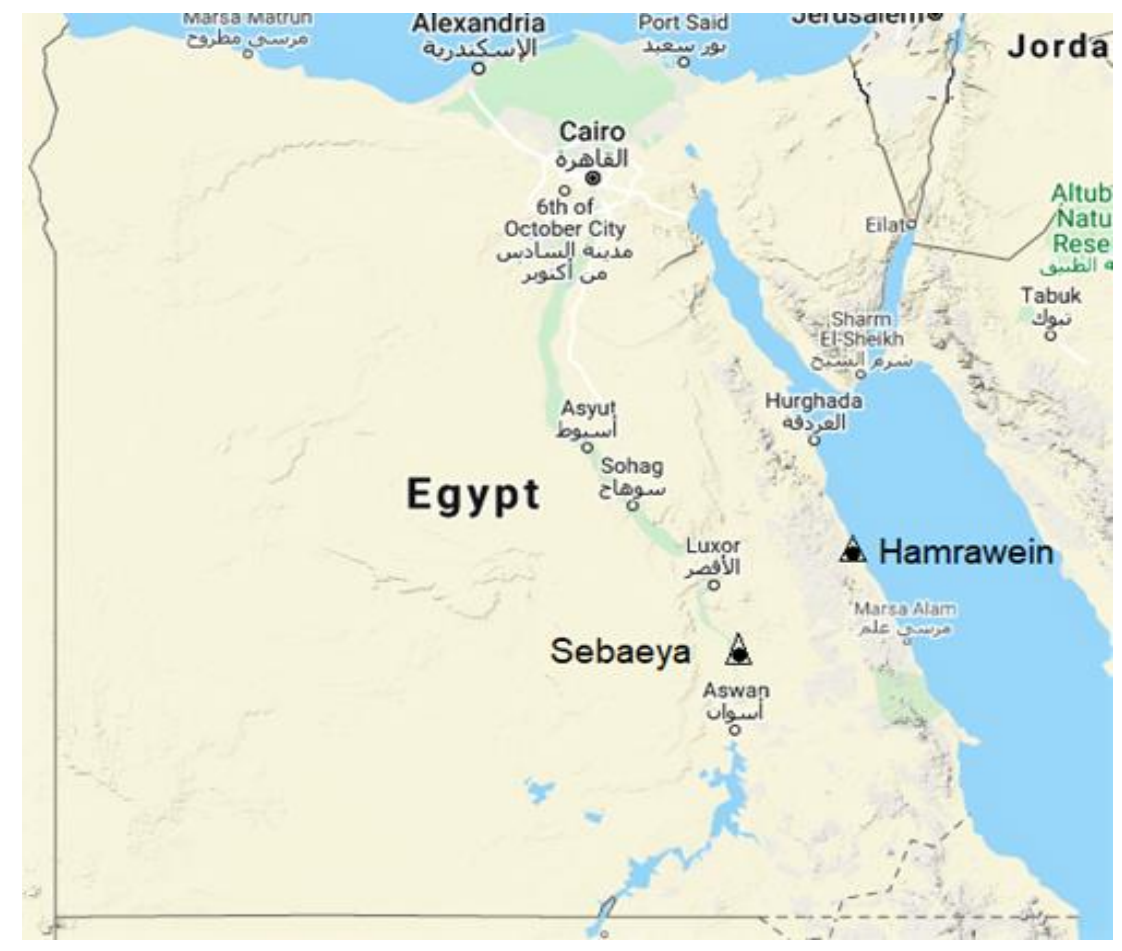

Fig. 1: Map of location of phosphate mines of Nasr mining company under study

Based on profit, the percentages of blending for some grades were as follows; for phosphate grade $31 \%$ P2O5, 90\% of the quantity should be taken from stockpile No.1 and 10\% from stockpile No.2. A required quantity of phosphate ore with grade $27 \%$ P2O5 is obtained by mixing $52.5 \%$ of the quantity from stockpile No.4, $40 \%$ from stockpile No.5 and 7.5\% from stockpile No.7. To obtain a phosphate grade of $22 \% \mathrm{P} 2 \mathrm{O} 5,27.6 \%$ of the required quantity should be taken from stockpile No.4, $15.6 \%$ from stockpile No.6 and 56.8\% from stockpile No.7.

\section{METHODOLOGY}

\subsection{Optimization of blending operation for phosphate mines based on selling price}

In this study, blending operation of three phosphate mines located in the Nile Valley, El-Sebaeya western area were optimized. The three mines have variations in amount of phosphate reserve and assay. Um Salamh mine has a reserve about 1565054.4 ton, Hegara mine has 2317830 ton and Badr 
mine has 1488719.9 ton. The average assays of those mines are $30.4 \%, 29.3 \% \& 25 \%$, respectively as shown in Table 1. The offers of selling price of phosphate ore according to assay (\%P2O5) which are required for market are tabulated in Table 2.[11]

Table 1: Reserve and average assay of three mines under study

\begin{tabular}{ccc}
\hline Mine & Reserve, ton & Av. assay (\% P205) \\
\hline Um Salamh & 1565054.4 & 30.4 \\
\hline Hegara & 2317830.0 & 29.3 \\
\hline Badr & 1488719.9 & 25.0 \\
\hline
\end{tabular}

Table 2: Selling price of phosphate ore according to \% $\mathbf{P 2 O 5 .}$

\begin{tabular}{cccccc}
\hline Selling assay, $\%$ P2O5 & $\mathbf{3 0}$ & $\mathbf{2 9}$ & $\mathbf{2 8}$ & $\mathbf{2 7}$ \\
\hline Selling price, $\$ /$ ton & 58 & 46 & 40 & 38 \\
\hline
\end{tabular}

The objective function to maximize blending operation is:

$$
58 *(\mathrm{X} 11+\mathrm{X} 21+\mathrm{X} 31)+46 *(\mathrm{X} 12+\mathrm{X} 22+\mathrm{X} 32)+40 *(\mathrm{X} 13+\mathrm{X} 23+\mathrm{X} 33)+38 *(\mathrm{X} 14+\mathrm{X} 24+\mathrm{X} 34)
$$

For solving this problem to obtain the optimal solution and satisfying the entire product specifications, the following constraints must be achieved:

$$
\begin{gathered}
X 11+X 12+X 13+X 14 \leq 1565054.4 \\
X 21+X 22+X 23+X 24 \leq 2317830 \\
X 31+X 32+X 33+X 34 \leq 1488719.9
\end{gathered}
$$

Amount of phosphate in blends must be equal to amount of the target assays:

$$
\begin{array}{r}
30.4 \mathrm{X} 11+29.3 \mathrm{X} 21+25 \mathrm{X} 31=30(\mathrm{X} 11+\mathrm{X} 21+\mathrm{X} 31) \\
30.4 \mathrm{X} 12+29.3 \mathrm{X} 22+25 \mathrm{X} 32=29(\mathrm{X} 12+\mathrm{X} 22+\mathrm{X} 32) \\
30.4 \mathrm{X} 13+29.3 \mathrm{X} 23+25 \mathrm{X} 33=28(\mathrm{X} 13+\mathrm{X} 23+\mathrm{X} 33) \\
30.4 \mathrm{X} 14+29.3 \mathrm{X} 24+25 \mathrm{X} 34=27(\mathrm{X} 14+\mathrm{X} 24+\mathrm{X} 34) \\
(\text { Non-negative }) \Sigma \mathrm{Xij} \geq 0
\end{array}
$$

Using Excel Software and Solver implementation to solve the problem, assign the parameters of the problem to Excel Sheet Cells as follows; the cells D4 through G6 represent the twelve decision variables (according to selling assays) and the cell A20 represents the objective function. The cells B10, B11, B12, B13, B14, B15, B16, B17 and B18 represent the constraints left hand side and the cells $\mathrm{C} 10, \mathrm{C} 11, \mathrm{C} 12, \mathrm{C} 13, \mathrm{C} 14, \mathrm{C} 15, \mathrm{C} 16, \mathrm{C} 17$ and $\mathrm{C} 18$ represent the constraints right hand side as shown in Figure 2. The non-negativity constraint is not implemented in the spreadsheet, and it can be implemented in the Solver.

From the data icon in menu bar in excel software, choose solver where complete set of constraints, target cell (objective function cell); variable cells and whether to maximize or minimize the objective function are identified in the Solver parameters box as shown in Figure 3. The optimal distribution of phosphate ore resulted from the optimization of blending process of the three mines is shown in Figure 4 , where the optimal solution of the objective function is illustrated in cell (A20). 
According to the previous solution of using maximization of selling price; all quantities of phosphate ores in the three mines will be exploited according to the blending process of the three mines. Because the blending process may be continuous or patch; the obtained quantities can be converted into percentages since the mixing process cannot be done at equal daily portions along the mine life as shown in Table 3. As well as blending process, the obtained percentages are shown in Figure 5.

\begin{tabular}{|c|c|c|c|c|c|c|c|}
\hline 4 & A & B & c & D & E & f & $G$ \\
\hline \multicolumn{8}{|l|}{1} \\
\hline \multirow{2}{*}{\multicolumn{2}{|c|}{ Mine }} & \multirow{2}{*}{ Reserve (ton) } & \multirow{2}{*}{ Av. assay $\left(\mathrm{XP}_{2} \mathrm{O}_{5}\right)$} & \multicolumn{4}{|c|}{ Selling assays $\left(X_{2}, O_{s}\right)$} \\
\hline & & & & $30 \%$ & $29 \%$ & $28 \%$ & $27 \%$ \\
\hline & Um Salamh & 1565054.4 & 30.4 & 0 & 0 & 0 & 0 \\
\hline 5 & Hegara & 2317830.0 & 29.3 & 0 & 0 & 0 & 0 \\
\hline 6 & Badr & 1488719.9 & 25.0 & 0 & 0 & 0 & 0 \\
\hline 7 & & & & \multicolumn{4}{|c|}{ Selline price $(\$ /$ ton) } \\
\hline 8 & & & & 58 & 46 & 40 & 38 \\
\hline 9 & & \multicolumn{2}{|c|}{ constraints } & & & & \\
\hline 10 & & 0 & 1565054.4 & & & & \\
\hline 11 & & 0 & 2317830.0 & & & & \\
\hline 12 & & 0 & 1488719.9 & & & & \\
\hline 13 & & 0 & 0 & & & & \\
\hline 14 & & 0 & 0 & & & & \\
\hline 15 & & 0 & 0 & & & & \\
\hline 16 & & 0 & 0 & & & & \\
\hline 17 & & 0 & 5371604.3 & & & & \\
\hline 18. & & 0 & 0 & & & & \\
\hline 19 & \multicolumn{2}{|c|}{ Objective function } & & & & & \\
\hline 20 & & 0 & & & & & \\
\hline
\end{tabular}

Fig. 2: Solving blending operation problem of three mines

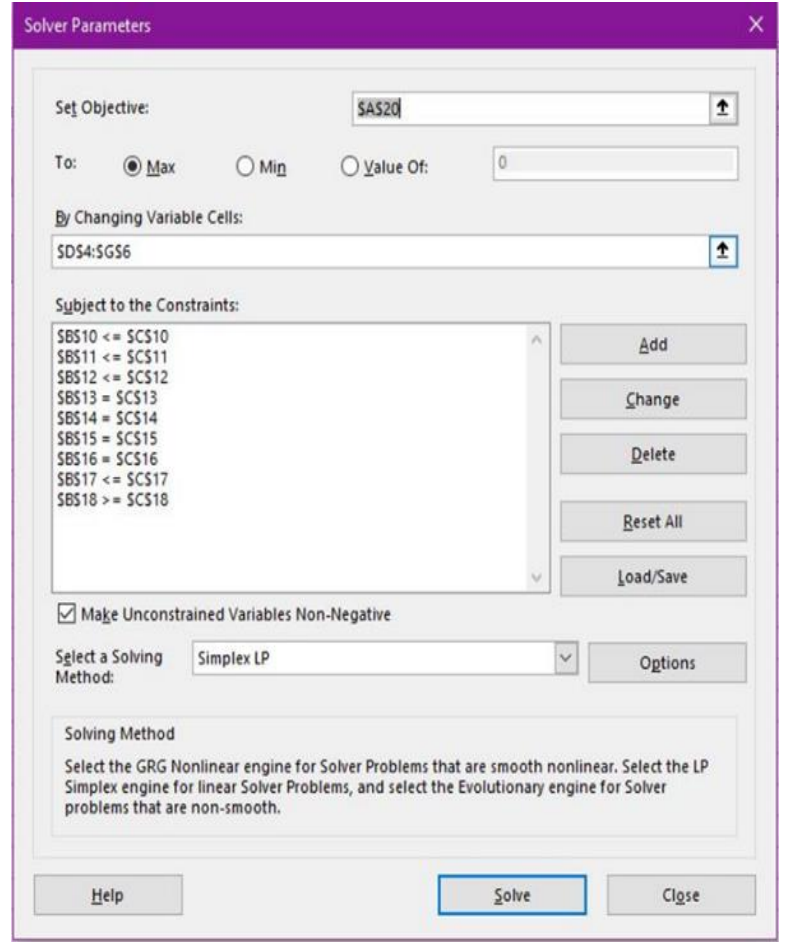

Fig. 3: Solver dialog box

Table 3: The percentages of phosphate obtained from three mines according to selling price

\begin{tabular}{ccccc}
\hline Mine & \multicolumn{4}{c}{ Selling Assays $\left(\boldsymbol{\%} \mathbf{P}_{\mathbf{2}} \mathbf{O}_{\mathbf{5}}\right)$} \\
\cline { 2 - 4 } & $\mathbf{3 0 \%}$ & $\mathbf{2 9 \%}$ & $\mathbf{2 8 \%}$ & $\mathbf{2 7 \%}$ \\
\hline Salamh & 92.6 & 0.0 & 11.8 & 0.0 \\
\hline Hegara & 0.0 & 0.0 & 54.9 & 0.0 \\
\hline Badr & 7.4 & 0.0 & 33.3 & 0.0
\end{tabular}


OPTIMIZATION OF BLENDING OPERATION FOR PHOSPHATE MINES AND STOCKPILES USING LINEAR PROGRAMMING TECHNIQUE IN MINING

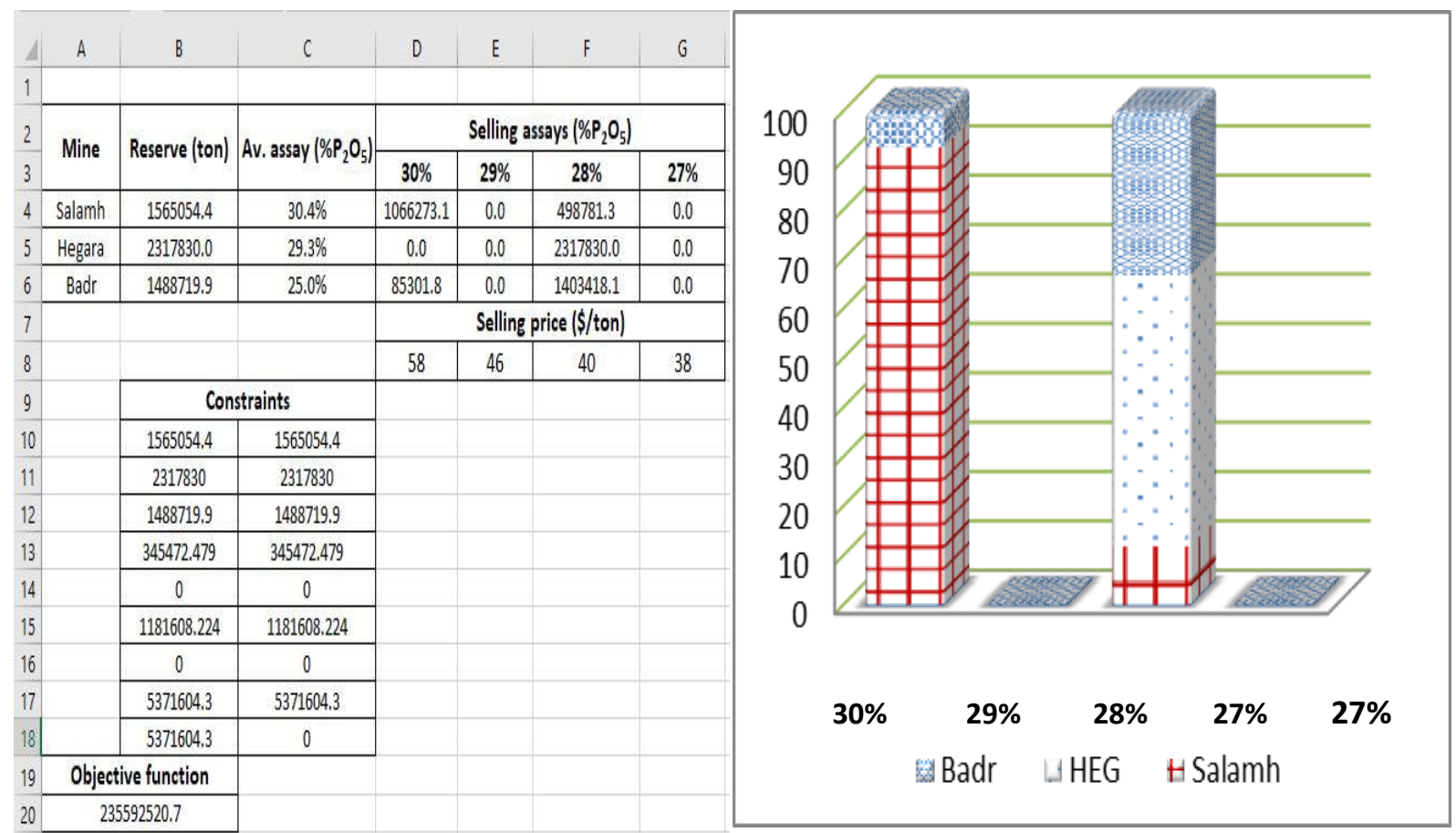

Fig. 4: Optimal solution on selling price-basis of three mines
Fig. 1: The percentages of phosphate ore obtained from three mines according to selling price

\subsection{Optimization of blending process of three mines according to profit-basis}

According to the profit definition, cost per ton of phosphate ore should be included into the objective function. The cost per ton of phosphate ore extracted from three mines is tabulated in Table 4 [12].

Table 4: Cost of production of phosphate ore

\section{Mine}

\section{Um Salamh}

Hegara

Badr

\section{Cost, \$/ton}

5.20

4.47

12.35

The objective function used to maximize the profit is written in the following formula:

$95.5 *(X 11+X 21+X 31)+80 *(X 12+X 22+X 32)+70 *(X 13+X 23+X 33)+50 *(X 14+$ $X 24+X 34)-5.2(X 11+X 12+X 13+X 14)-4.47 *(X 21+X 22+X 23+X 24)-12.35 *$

$(X 31+X 32+X 33+X 34) \quad$ By applying excel software and using solver implementation to solve the problem, assign the parameters of the problem to excel sheet. The obtained results are shown in Fig. 2 and summarized in Table 5. The obtained percentages of phosphate from three mines according to profit are shown in Table 6 and Fig. 3. 
OPTIMIZATION OF BLENDING OPERATION FOR PHOSPHATE MINES AND STOCKPILES USING LINEAR PROGRAMMING TECHNIQUE IN MINING

Table 5: The optimal solution of maximization of blending process of three mines according to the profit

\begin{tabular}{|c|c|c|c|c|c|c|}
\hline \multirow[t]{2}{*}{ Mine } & \multirow[t]{2}{*}{ Reserve (ton) } & \multirow[t]{2}{*}{ Av. assay $\left(\% \mathbf{P}_{2} \mathbf{O}_{5}\right)$} & \multicolumn{4}{|c|}{ Selling assays $\left(\% \mathbf{P}_{2} \mathbf{O}_{5}\right)$} \\
\hline & & & 30 & 29 & 28 & 27 \\
\hline Salamh & 1565054.4 & 30.40 & 1565054.4 & 0.0 & 0.0 & 0.0 \\
\hline Hegara & 2317830.0 & 29.30 & 894316.8 & 137972.4 & 0.0 & 1285540.8 \\
\hline Badr & 1488719.9 & 25.00 & 0.0 & 10347.9 & 0.0 & 1478372.0 \\
\hline \multicolumn{7}{|c|}{ Table 6: The percentages of phosphate obtained from three mines according to profit } \\
\hline \multirow{2}{*}{\multicolumn{2}{|c|}{ Mine }} & \multicolumn{5}{|c|}{ Selling Assays $\left(\% \mathbf{P}_{2} \mathbf{O}_{5}\right)$} \\
\hline & & $30 \%$ & & $28 \%$ & & $27 \%$ \\
\hline Sala & nh & 63.6 & & 0.0 & & 0.0 \\
\hline Heg & & 36.4 & & 0.0 & & 46.5 \\
\hline $\mathbf{B a}$ & & 0.0 & & 0.0 & & 53.5 \\
\hline
\end{tabular}

\begin{tabular}{|c|c|c|c|c|c|c|c|c|}
\hline 4 & A & B & c & D & E & $\mathrm{F}$ & G & H \\
\hline 2 & \multirow{2}{*}{ Mine } & \multirow{2}{*}{ Reserve (ton) } & \multirow{2}{*}{ Av. assay $\left(\% \mathrm{P}_{2} \mathrm{O}_{5}\right)$} & \multicolumn{4}{|c|}{ Selling assays $\left(\% \mathrm{P}_{2} \mathrm{O}_{5}\right)$} & \multirow{2}{*}{ Cost $\$ /$ ton } \\
\hline 3 & & & & $30 \%$ & $29 \%$ & $28 \%$ & $27 \%$ & \\
\hline 4 & Salamh & 1565054.4 & $30 \%$ & 1565054,4 & 0.0 & 0.0 & 0.0 & 5.20 \\
\hline 5 & Hegara & 2317830.0 & $29 \%$ & 894316.8 & 137972.4 & 0.0 & 1285540.8 & 4.47 \\
\hline 6 & Badr & 1488719.9 & $25 \%$ & 0.0 & 10347.9 & 0.0 & 1478372.0 & 12.35 \\
\hline 7 & & & & \multicolumn{4}{|c|}{ Selling price $(\$ \$$ ton $)$} & \\
\hline 8 & & & & 58 & 46 & 40 & 38 & \\
\hline 9 & & \multicolumn{2}{|c|}{ constraints } & & & & & \\
\hline 10 & & 1565054.4 & 1565054.4 & & & & & \\
\hline 11 & & 2317830.0 & 2317830.0 & & & & & \\
\hline 12 & & 1488719.9 & 1488719.9 & & & & & \\
\hline 13 & & 737811.4 & 737811.4 & & & & & \\
\hline 14 & & 43012.9 & 43012.9 & & & & & \\
\hline 15 & & 0.0 & 0.0 & & & & & \\
\hline 16 & & 746256.5 & 746256.5 & & & & & \\
\hline 17 & & 5371604.3 & 5371604.3 & & & & & \\
\hline 18 & & 5371604.3 & 0.0 & & & & & \\
\hline 19 & & 1565054.4 & 1565054.4 & & & & & \\
\hline 20 & & 2317830.0 & 2317830.0 & & & & & \\
\hline 21 & & 1488719.9 & 1488719.9 & & & & & \\
\hline 22 & \multicolumn{2}{|c|}{ objective function } & & & & & & \\
\hline 23 & & 510275.9 & & & & & & \\
\hline
\end{tabular}

Fig. 2: The optimal solution of maximization of blending process of three mines according to the profit

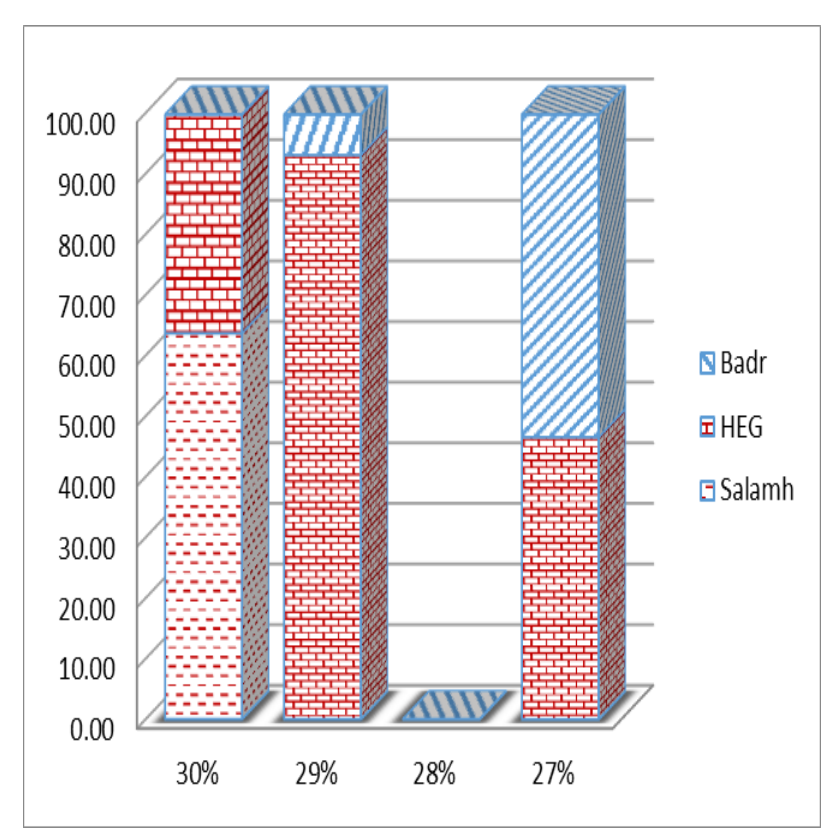

Fig. 3: The percentages of phosphate obtained from three mines according to profit

\subsection{Optimization of blending operation for phosphate Stockpiles based on selling price}

Nasr Mining Co. has seven stockpiles reserves with different quantities and grades as shown in Table 7. These stockpiles are composed from different mines in Sebaeya and Hamrawein areas. The selling prices of the assays are tabulated in

Table 8 [13]. 
OPTIMIZATION OF BLENDING OPERATION FOR PHOSPHATE MINES AND STOCKPILES USING LINEAR PROGRAMMING TECHNIQUE IN MINING

Table 7: Reserves and average assays of stockpiles under study

\begin{tabular}{ccc}
\hline Pile & Reserve (ton) & Av. assay (\% $\left.\mathbf{P}_{\mathbf{2}} \mathbf{O}_{\mathbf{5}}\right)$ \\
\hline $\mathbf{1}$ & 937.50 & 31.10 \\
\hline $\mathbf{2}$ & 85069.18 & 30.10 \\
\hline $\mathbf{3}$ & 69688.68 & 29.10 \\
\hline $\mathbf{4}$ & 153602.00 & 28.00 \\
\hline $\mathbf{5}$ & 85148.60 & 27.30 \\
\hline $\mathbf{6}$ & 20247.60 & 24.50 \\
\hline $\mathbf{7}$ & 89535.00 & 18.40 \\
\hline
\end{tabular}

Table 8: Selling prices of phosphate according to $\% \mathrm{P}_{2} \mathrm{O}_{5}$

\begin{tabular}{cccccccccc}
\hline Assay, $\% \mathbf{P}_{2} \mathbf{O}_{5}$ & $\mathbf{3 1}$ & $\mathbf{3 0}$ & $\mathbf{2 9}$ & $\mathbf{2 8}$ & $\mathbf{2 7}$ & $\mathbf{2 6}$ & $\mathbf{2 5}$ & $\mathbf{2 4}$ & $\mathbf{2 2}$ \\
\hline Price (\$/ton) & 73 & 58 & 46 & 40 & 38 & 32 & 26 & 25 & 20
\end{tabular}

The objective function of blending operation of stockpiles according to selling price is as follows:

$$
\begin{aligned}
& 73 *(X 11+X 21+X 31+X 41+X 51+X 61+X 71)+58 \\
& *(X 12+X 22+X 32+X 42+X 52+X 62+X 72)+46 \\
& *(X 13+X 23+X 33+X 43+X 53+X 63+X 73)+40 \\
& *(X 14+X 24+X 34+X 44+X 54+X 64+X 74)+38 \\
& *(X 15+X 25+X 35+X 45+X 55+X 65+X 75)+32 \\
& *(X 16+X 26+X 36+X 46+X 56+X 66+X 76)+26 \\
& *(X 17+X 27+X 37+X 47+X 57+X 67+X 77)+25 *(X 18+X 28+X 38 \\
&+X 48+X 58+X 68+X 78)+20 \\
& *(X 19+X 29+X 39+X 49+X 59+X 69+X 79)
\end{aligned}
$$

For solving this problem to obtain the maximum profit and satisfying the entire product specifications, the following constraints must be achieved:

$$
\begin{aligned}
& (X 11+X 12+X 13+X 14+X 15+X 16+X 17+X 18+X 19) \leq 937.50 \\
& (X 21+X 22+X 23+X 24+X 25+X 26+X 27+X 28+X 29) \leq 85069.18 \\
& (X 31+X 32+X 33+X 34+X 35+X 36+X 37+X 38+X 39) \leq 69688.68 \\
& (X 41+X 42+X 43+X 44+X 45+X 46+X 47+X 48+X 49) \leq 153602.0 \\
& (X 51+X 52+X 53+X 54+X 55+X 56+X 57+X 58+X 59) \leq 85148.60 \\
& (X 61+X 62+X 63+X 64+X 65+X 66+X 67+X 68+X 69) \leq 20247.60 \\
& (X 71+X 72+X 73+X 74+X 75+X 76+X 77+X 78+X 79) \leq 89535.00
\end{aligned}
$$

Amount of phosphate in blends must be equal to the amount of target assays, as follows:

$$
\begin{gathered}
31.1 X 11+30.1 X 21+29.1 X 31+28.00 X 41+27.3 X 51+24.5 X 61+18.4 X 71 \\
=31(X 11+X 21+X 31+X 41+X 51+X 61+X 71)
\end{gathered}
$$


OPTIMIZATION OF BLENDING OPERATION FOR PHOSPHATE MINES AND STOCKPILES USING LINEAR PROGRAMMING TECHNIQUE IN MINING

$$
\begin{gathered}
31.1 X 12+30.1 X 22+29.1 X 32+28.0 X 42+27.3 X 52+24.5 X 62+18.4 X 72 \\
=30(X 12+X 22+X 32+X 42+X 52+X 62+X 72) \\
31.1 X 13+30.1 X 23+29.1 X 33+28.0 X 43+27.3 X 53+24.5 X 63+18.4 X 73 \\
=29(X 13+X 23+X 33+X 43+X 53+X 63+X 73) \\
31.1 X 14+30.1 X 24+29.1 X 34+28.0 X 44+27.3 X 54+24.5 X 64+18.4 X 74 \\
=28(X 14+X 24+X 34+X 44+X 54+X 64+X 74) \\
31.1 X 15+30.1 X 25+29.1 X 35+28.0 X 45+27.3 X 55+24.5 X 65+18.4 X 75 \\
=27(X 15+X 25+X 35+X 45+X 55+X 65+X 75) \\
31.1 X 16+30.1 X 26+29.1 X 36+28.0 X 46+27.3 X 56+24.5 X 66+18.4 X 76 \\
=26(X 16+X 26+X 36+X 46+X 56+X 66+X 76) \\
31.1 X 17+30.1 X 27+29.1 X 37+28.0 X 47+27.3 X 57+24.5 X 67+18.4 X 77 \\
=25(X 17+X 27+X 37+X 47+X 57+X 67+X 77) \\
31.1 X 18+30.1 X 28+29.1 X 38+28.0 X 48+27.3 X 58+24.5 X 68+18.4 X 78 \\
=24(X 18+X 28+X 38+X 48+X 58+X 68+X 78) \\
31.1 X 19+30.1 X 29+29.1 X 39+28.0 X 49+27.3 X 59+24.5 X 69+18.4 X 79 \\
=22(X 19+X 29+X 39+X 49+X 59+X 69+X 79) \\
(\text { Non }- \text { negative }) \Sigma X i j \geq 0
\end{gathered}
$$

\section{$\Sigma X i j=$ total quantities of phosphate ores in stockpiles}

By using Excel Software and Solver implementation to solve the problem, the parameters of the problem are assigned to Excel Sheet cells as follows; the cells D3 through L9 represent the sixty-three decision variables (according to selling price of assays) and the cell D14 represents the objective function. The cells A12: A29 represent the constraints left hand sides, and the cells B12: B29 represent the constraints right hand sides as shown in Fig. 4. The non-negativity constraint is not implemented in the spreadsheet, and it can be implemented in the Solver.

Complete set of constraints, target cell (objective function cell); variables cells and the maximization of the objective function are identified in the Solver parameters box as shown in Fig. 5. The optimal distribution of phosphate ores in the blending process is shown in 6. The optimal solution of the objective function is shown in the cell (D14). The percentages of blending process are shown in Table 9) and Fig. 7. 
OPTIMIZATION OF BLENDING OPERATION FOR PHOSPHATE MINES AND STOCKPILES USING LINEAR PROGRAMMING TECHNIQUE IN MINING

\begin{tabular}{|c|c|c|c|c|c|c|c|c|c|c|c|c|}
\hline \multicolumn{2}{|c|}{$A$} & B & c & D & E & $\mathrm{F}$ & G & H & 1 & J & k & L \\
\hline 1 & & & & \multicolumn{9}{|c|}{ Selling Assays } \\
\hline 2 & Pile & \begin{tabular}{|l|} 
Reserve (ton) \\
\end{tabular} & Av. Assay (\%P205) & $31.00 \%$ & $30.00 \%$ & $29.00 \%$ & $28.00 \%$ & $27.00 \%$ & $26.00 \%$ & $25.00 \%$ & $24.00 \%$ & $22.00 \%$ \\
\hline 3 & 1 & 937.5 & $31.10 \%$ & 0 & 0 & 0 & 0 & 0 & 0 & 0 & 0 & 0 \\
\hline 4 & 2 & 85069.18 & $30.10 \%$ & 0 & 0 & 0 & 0 & 0 & 0 & 0 & 0 & 0 \\
\hline 5 & 3 & 69688.68 & $29.10 \%$ & 0 & 0 & 0 & 0 & 0 & 0 & 0 & 0 & 0 \\
\hline 6 & 4 & 153602 & $28.00 \%$ & 0 & 0 & 0 & 0 & 0 & 0 & 0 & 0 & 0 \\
\hline 7 & 5 & 85148.6 & $27.30 \%$ & 0 & 0 & 0 & 0 & 0 & 0 & 0 & 0 & 0 \\
\hline 8 & 6 & 20247.6 & $24.50 \%$ & 0 & 0 & 0 & 0 & 0 & 0 & 0 & 0 & 0 \\
\hline 9 & 7 & 89535 & $18.40 \%$ & 0 & 0 & 0 & \begin{tabular}{l|}
0 \\
\end{tabular} & 0 & 0 & 0 & 0 & 0 \\
\hline 10 & & & \multicolumn{10}{|c|}{ Selling price (\$/ton) } \\
\hline 11 & \multicolumn{2}{|r|}{ Constraints } & & 73 & 58 & \begin{tabular}{|l|}
46 \\
\end{tabular} & \begin{tabular}{|l|}
40 \\
\end{tabular} & 38 & 32 & 26 & 25 & 20 \\
\hline 12 & 0 & 937.5 & & & & & & & & & & \\
\hline 13 & 0 & 85069.18 & & \multicolumn{3}{|c|}{ Objective funcion } & & & & & & \\
\hline $14^{\prime}$ & 0 & 69688.68 & & & 0 & & & & & & & \\
\hline 15 & 0 & 153602 & & & & & & & & & & \\
\hline 16 & 0 & 85148.6 & & & & & & & & & & \\
\hline 17 & 0 & 20247.6 & & & & & & & & & & \\
\hline $18{ }^{1}$ & 0 & 89535 & & & & & & & & & & \\
\hline 19 . & 0 & 0 & & & & & & & & & & \\
\hline 20 & 0 & 0 & & & & & & & & & & \\
\hline 21 & 0 & 0 & & & & & & & & & & \\
\hline 22 . & 0 & 0 & & & & & & & & & & \\
\hline 23. & 0 & 0 & & & & & & & & & & \\
\hline 24 . & 0 & 0 & & & & & & & & & & \\
\hline 25. & 0 & 0 & & & & & & & & & & \\
\hline 26 & 0 & 0 & & & & & & & & & & \\
\hline 27. & 0 & 0 & & & & & & & & & & \\
\hline 28 & 0 & 504228.56 & & & & & & & & & & \\
\hline 29. & 0 & 0 & & & & & & & & & & \\
\hline
\end{tabular}

Fig. 4: Solving of blending operation problem of seven stockpiles into Excel Sheet Software

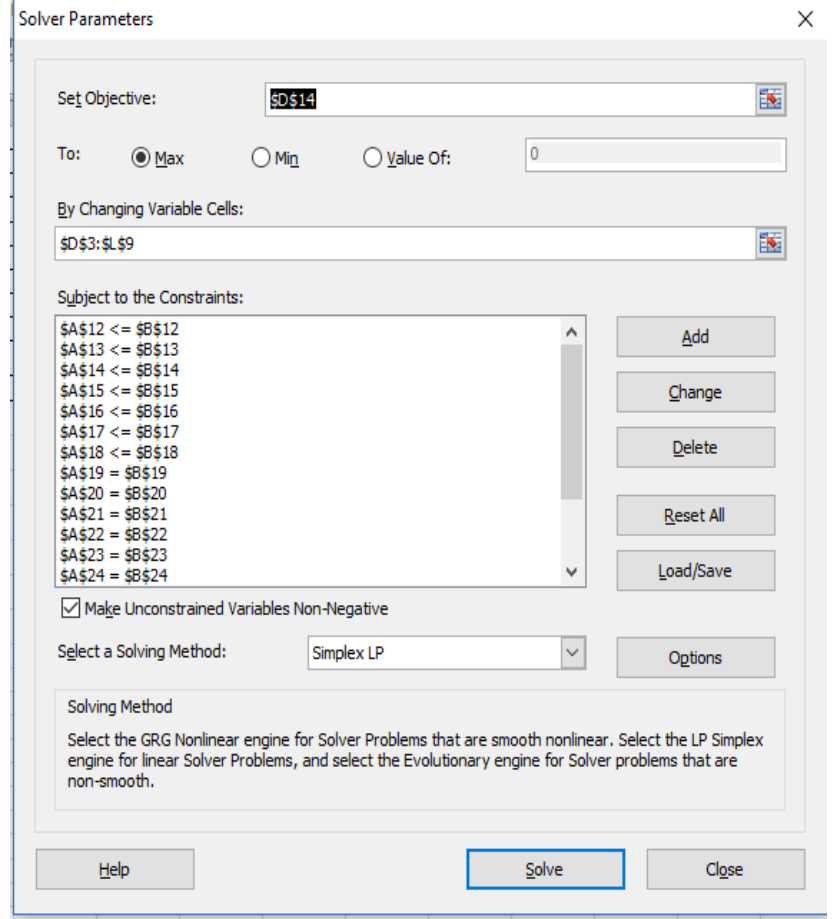

Fig. 5: Solver dialog box of optimization of blending operation of stockpiles

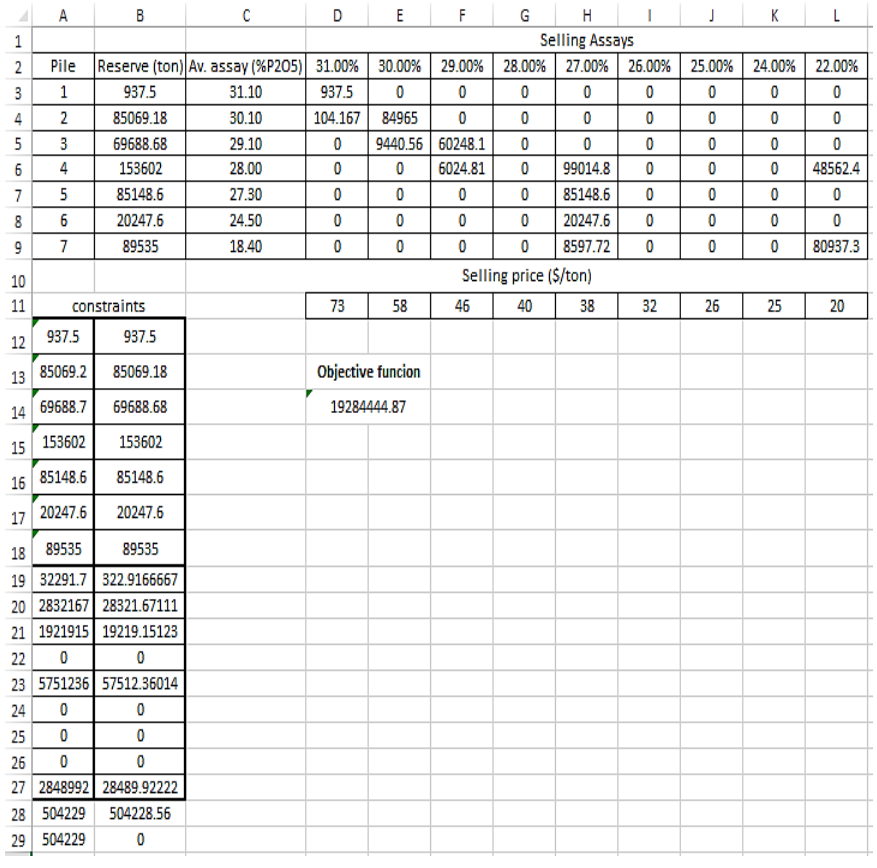

Fig. 6: Optimal solution of stockpiles according to selling price

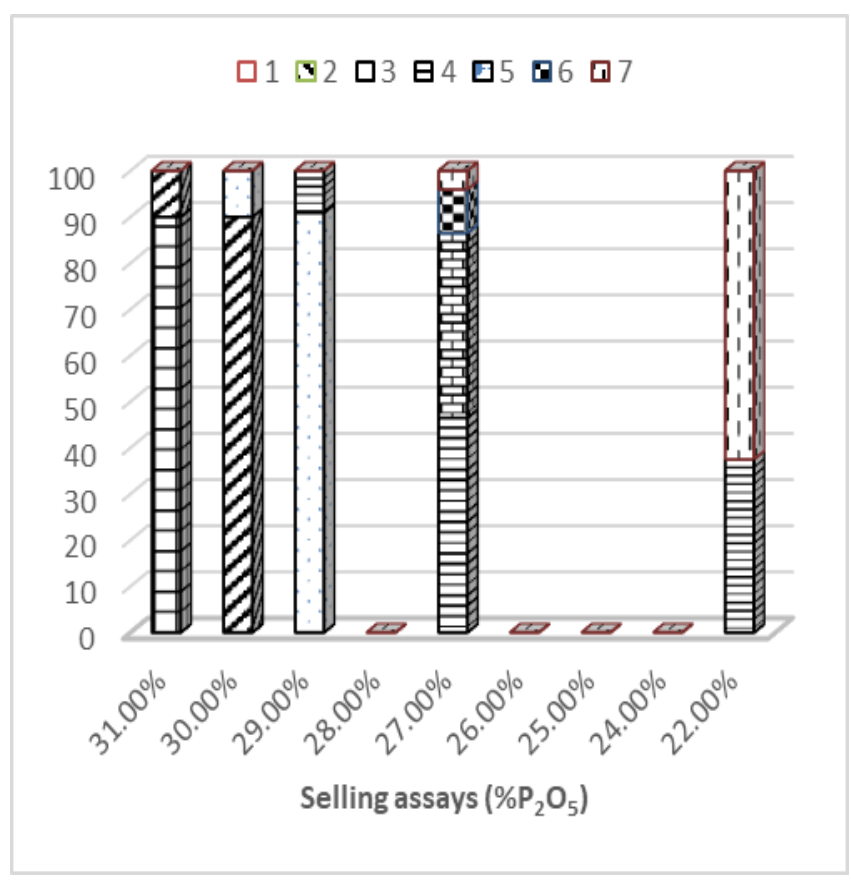

Fig. 7: Blending percentages of phosphate obtained from phosphate stockpiles 
OPTIMIZATION OF BLENDING OPERATION FOR PHOSPHATE MINES AND STOCKPILES USING LINEAR PROGRAMMING TECHNIQUE IN MINING

Table 9: Blending percentages of phosphate obtained from phosphate stockpiles according to selling price

\begin{tabular}{|c|c|c|c|c|c|c|c|c|c|}
\hline \multirow[t]{2}{*}{ Pile } & \multicolumn{9}{|c|}{ Selling assays $\left(\% \mathbf{P}_{2} \mathrm{O}_{5}\right)$} \\
\hline & 31 & 30 & 29 & 28 & 27 & 26 & 25 & 24 & 22 \\
\hline 1 & 90.0 & 0.0 & 0.0 & 0.0 & 0.0 & 0.0 & 0.0 & 0.0 & 0.0 \\
\hline 2 & 10.0 & 90.0 & 0.0 & 0.0 & 0.0 & 0.0 & 0.0 & 0.0 & 0.0 \\
\hline 3 & 0.0 & 10.0 & 90.9 & 0.0 & 0.0 & 0.0 & 0.0 & 0.0 & 0.0 \\
\hline 4 & 0.0 & 0.0 & 9.1 & 0.0 & 46.5 & 0.0 & 0.0 & 0.0 & 37.5 \\
\hline 5 & 0.0 & 0.0 & 0.0 & 0.0 & 40.0 & 0.0 & 0.0 & 0.0 & 0.0 \\
\hline 6 & 0.0 & 0.0 & 0.0 & 0.0 & 9.5 & 0.0 & 0.0 & 0.0 & 0.0 \\
\hline 7 & 0.0 & 0.0 & 0.0 & 0.0 & 4.0 & 0.0 & 0.0 & 0.0 & 62.5 \\
\hline
\end{tabular}

\subsection{Stockpiles optimization according to profit}

As shown before, it is necessary to use the profit as a controlling factor instead of the selling price for the optimization of blending problem of the stockpiles. The cost per ton of these stockpiles is shown in Table 10 [12].

Table 10: Cost of phosphate ore of the stockpiles

Pile Cost, $\$ /$ ton

\begin{tabular}{ll}
\hline $\mathbf{1}$ & 7.58 \\
$\mathbf{2}$ & 7.65 \\
\hline $\mathbf{3}$ & 7.61 \\
\hline $\mathbf{4}$ & 7.88 \\
\hline $\mathbf{5}$ & 7.74 \\
\hline $\mathbf{6}$ & 5.76 \\
\hline $\mathbf{7}$ & 5.88
\end{tabular}

The objective function according to profit can be written as follows:

$$
\begin{aligned}
& 73 *(X 11+X 21+X 31+X 41+X 51+X 61+X 71)+58 *(X 12+X 22+X 32+X 42+X 52+ \\
& X 62+X 72)+46 *(X 13+X 23+X 33+X 43+X 53+X 63+X 73)+40 *(X 14+X 24+X 34+ \\
& X 44+X 54+X 64+X 74)+38 *(X 15+X 25+X 35+X 45+X 55+X 65+X 75)+32 * \\
& (X 16+X 26+X 36+X 46+X 56+X 66+X 76)+26 *(X 17+X 27+X 37+X 47+X 57+ \\
& X 67+X 77)+25 *(X 18+X 28+X 38+X 48+X 58+X 68+X 78)+20 *(X 19+X 29+X 39+ \\
& X 49+X 59+X 69+X 79)-7.58(X 11+X 12+X 13+X 14+X 15+X 16+X 17+X 18+X 19)- \\
& 7.65 *(X 21+X 22+X 23+X 24+X 25+X 26+X 27+X 28+X 29)-7.61(X 31+X 32+X 33+ \\
& X 34+X 35+X 36+X 37+X 38+X 39)-7.88 *(X 41+X 42+X 43+X 44+X 45+X 46+ \\
& X 47+X 48+X 49)-7.74 *(X 51+X 52+X 53+X 54+X 55+X 56+X 57+X 58+X 59)-
\end{aligned}
$$




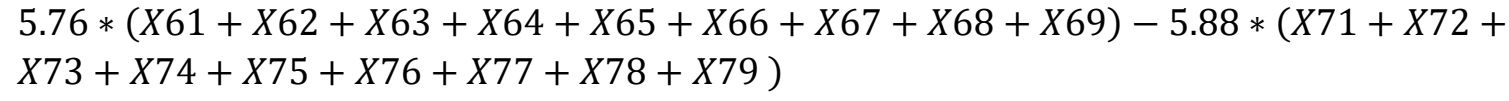

To use Excel Software and Solver implementation to solve the problem, assign the parameters of the problem to Excel Sheet Cells as follows; the cells D3 through L9 represent the sixty-three decision variables (according to selling assays) and the cell D14 represents the objective function. The cells A12:A29 represent the constraints left hand sides and the cells B12:B29 represent the constraints right hand sides, cost \$/ton is represented in the cells M3:M9 as shown in 8. The non-negativity constraint is not implemented in the spreadsheet, and it can be implemented in the Solver.

The optimal solution of the optimization blending problem of the stockpiles phosphate ore according to profit is shown in figure 13. The percentage of blending process are shown in

Table $11 \&$ Fig. 10. when optimization was carried out using profit, the optimum percentages of blending processes were as follows:

For phosphate grade of $31 \% \mathrm{P}_{2} \mathrm{O}_{5}, 90 \%$ of the quantity should be taken from stockpile No. 1 and $10 \%$ from stockpile No. 2. For phosphate grade of $30 \% \mathrm{P}_{2} \mathrm{O}_{5}$, the required quantity is obtained by mixing $90 \%$ of the quantity from stockpile No. 2 and $10 \%$ from stockpile No. 3. A specified quantity of phosphate ore with grade of $29 \% \mathrm{P}_{2} \mathrm{O}_{5}$, should be composed by blending $90.1 \%$ of the quantity from stockpile No. 3 and $9.9 \%$ from stockpile No. 4. A required quantity of phosphate ore with grade of $27 \% \mathrm{P}_{2} \mathrm{O}_{5}$ is obtained by mixing $52.5 \%$ of the quantity from stockpile No. $4,40 \%$ from stockpile No. 5 , and $7.5 \%$ from stockpile No.7. To obtain a phosphate grade of $22 \% \mathrm{P}_{2} \mathrm{O}_{5}, 27.6 \%$ of the required quantity should be taken from stockpile No. 4, 15.6\% from stockpile No. 6 and 56.8\% from stockpile No. 7.

\begin{tabular}{|c|c|c|c|c|c|c|c|c|c|c|c|c|c|}
\hline 1 & & $B$ & $\mathrm{c}$ & \multicolumn{8}{|c|}{ Selling Assays } & L & \multirow{2}{*}{$\frac{M}{\operatorname{cost} s / t 0}$} \\
\hline & ile & Reserve (ton) & Assay (\%p205) & $31.00 \%$ & $30.00 \%$ & $29.0 \%$ & $28.00 \%$ & $27.00 \%$ & $626.00 \%$ & $25.00 \%$ & $24,00 \%$ & $22.00 \%$ & \\
\hline 3 & 1 & 937.5 & 31.10 & 0 & 0 & 0 & 0 & 0 & 0 & 0 & 0 & 0 & 7.58 \\
\hline 4 & 2 & 85069.18 & 30,10 & 0 & 0 & 0 & 0 & 0 & 0 & 0 & 0 & 0 & 7,65 \\
\hline 5 & 3 & 69688.68 & 29.10 & 0 & 0 & 0 & 0 & 0 & 0 & 0 & 0 & 0 & 7.61 \\
\hline 6 & 4 & 1536022 & 28.00 & 0 & 0 & 0 & 0 & 0 & 0 & 0 & 0 & 0 & 7.88 \\
\hline 7 & 5 & 85148.6 & 27.30 & 0 & 0 & 0 & 0 & 0 & 0 & 0 & 0 & 0 & 7.74 \\
\hline 8 & 6 & 20277.6 & 24,50 & 0 & 0 & 0 & 0 & 0 & 0 & 0 & 0 & 0 & 5.76 \\
\hline 9 & 7 & 89535 & 18.40 & 0 & 0 & 0 & 0 & 0 & 0 & 0 & 0 & 0 & 5.88 \\
\hline 10 & & & \multicolumn{10}{|c|}{ Selling price (\$/ton) } & \\
\hline & \multicolumn{2}{|c|}{ Constraints } & & 73 & 58 & 46 & 40 & 38 & 32 & 26 & 25 & 20 & \\
\hline & 0 & \begin{tabular}{|l|}
937.5 \\
\end{tabular} & & & & & & & & & & & \\
\hline 13 & & 850699.18 & & Objectii & le funcion & & & & & & & & \\
\hline $144^{\prime \prime}$ & 0 & 69688.68 & & & 0 & & & & & & & & \\
\hline 15 & 0 & 153602 & & & & & & & & & & & \\
\hline 16 " & 0 & 85548.6 & & & & & & & & & & & \\
\hline $177^{\prime}$ & 0 & 20247.6 & & & & & & & & & & & \\
\hline 18 ". & 0 & 899535 & & & & & & & & & & & \\
\hline 197 & 0 & 0 & & & & & & & & & & & \\
\hline 20 & 0 & 0 & & & & & & & & & & & \\
\hline 21 & 0 & 0 & & & & & & & & & & & \\
\hline 22. & 0 & 0 & & & & & & & & & & & \\
\hline 23 & 0 & 0 & & & & & & & & & & & \\
\hline 24 & 0 & 0 & & & & & & & & & & & \\
\hline 25 & 0 & 0 & & & & & & & & & & & \\
\hline 26 & 0 & 0 & & & & & & & & & & & \\
\hline 27. & 0 & 0 & & & & & & & & & & & \\
\hline 28 & 0 & 504228.56 & & & & & & & & & & & \\
\hline 29 & 0 & 0 & & & & & & & & & & & \\
\hline
\end{tabular}

Fig. 8: Stockpiles parameters including cost into excel sheet

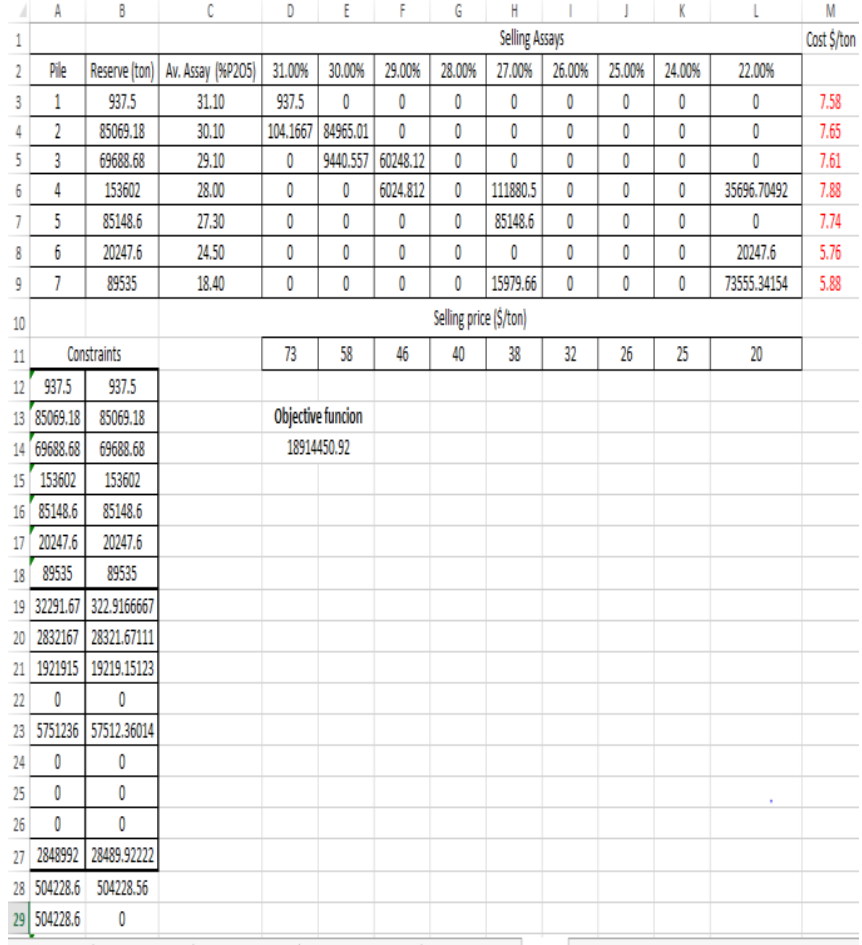

Fig. 9: The optimal solution of the optimization blending problem of the stockpiles according to profit 
OPTIMIZATION OF BLENDING OPERATION FOR PHOSPHATE MINES AND STOCKPILES USING LINEAR PROGRAMMING TECHNIQUE IN MINING

Table 11: Blending percentages of stockpiles according to profit

\begin{tabular}{|c|c|c|c|c|c|c|c|c|c|}
\hline \multirow[t]{2}{*}{ Pile } & \multicolumn{9}{|c|}{ Selling Assays $\left(\% \mathrm{P}_{2} \mathrm{O}_{5}\right)$} \\
\hline & 31 & 30 & 29 & 28 & 27 & 26 & 25 & 24 & 22 \\
\hline 1 & 90.0 & 0.0 & 0.0 & 0.0 & 0.0 & 0.0 & 0.0 & 0.0 & 0.0 \\
\hline 2 & 10.0 & 90.0 & 0.0 & 0.0 & 0.0 & 0.0 & 0.0 & 0.0 & 0.0 \\
\hline 3 & 0.0 & 10.0 & 90.9 & 0.0 & 0.0 & 0.0 & 0.0 & 0.0 & 0.0 \\
\hline 4 & 0.0 & 0.0 & 9.1 & 0.0 & 52.5 & 0.0 & 0.0 & 0.0 & 27.6 \\
\hline 5 & 0.0 & 0.0 & 0.0 & 0.0 & 40.0 & 0.0 & 0.0 & 0.0 & 0.0 \\
\hline 6 & 0.0 & 0.0 & 0.0 & 0.0 & 0.0 & 0.0 & 0.0 & 0.0 & 15.6 \\
\hline 7 & 0.0 & 0.0 & 0.0 & 0.0 & 7.5 & 0.0 & 0.0 & 0.0 & 56.8 \\
\hline
\end{tabular}

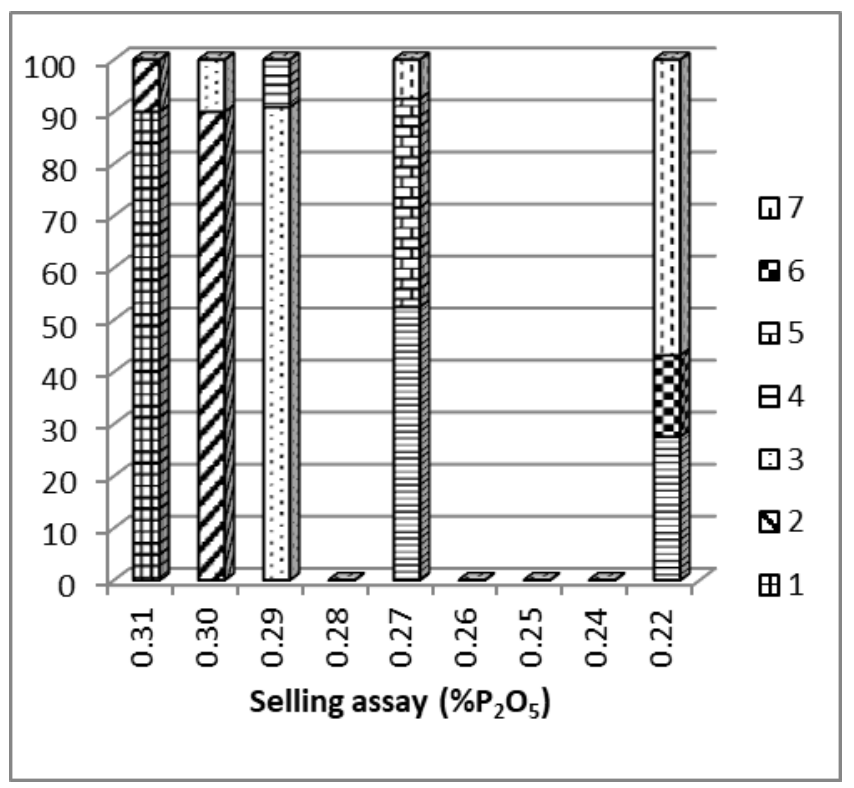

Fig. 10: Blending percentages of stockpiles according to profit

\section{RESULTS AND DISCUSSION}

Optimization of blending process of phosphate ore using linear programming technique was applied. It was adopted to determine the optimum quantities of three mines in Sebaeya area in Aswan.

In case of three mines, by using selling price in the objective function, the optimum results were as follows: A specified quantity of phosphate ore with grade of 30\% P2O5 is obtained by mixing $92.6 \%$ of the quantity from Salamh mine and $7.4 \%$ from Badr mine. For grade of $28 \%$ P2O5, the optimum quantity is obtained by blending $11.8 \%$ of the quantity from Salamh mine, $54.9 \%$ from Hegara mine and $33.3 \%$ from Badr mine. 
By using profit in the objective function, the optimum results were as follows. A specified quantity of phosphate ore with grade of $30 \% \mathrm{P}_{2} \mathrm{O}_{5}$ is obtained by mixing $63.6 \%$ of the quantity from Salamh mine and $36.4 \%$ from Hegara mine. For grade of $29 \% \mathrm{P}_{2} \mathrm{O}_{5}$, the optimum quantity is obtained by blending 93.0\% of the quantity from Hegara mine, $7 \%$ from Badr mine. It is not recommended to sell the grade of $28 \% \mathrm{P}_{2} \mathrm{O}_{5}$. A specified quantity of phosphate ore with grade of $27 \% \mathrm{P}_{2} \mathrm{O}_{5}$ is obtained by mixing $46.5 \%$ of the quantity from Salamh mine and $53.5 \%$ from Badr mine.

Comparing the results of blending process of selling price and profit, it can be shown that there are differences in the obtained phosphate quantities there is a big difference in the value of the objective function (optimal solution) with about 18 million dollars in case of executing the optimization according to profit basis.

For the optimization of the blending process of phosphate stockpiles located in Hamrawein area, by using selling price as an objective function, the optimum results were summarized as follows:

- To obtain phosphate grade of $31 \% \mathrm{P} 2 \mathrm{O} 5,90 \%$ of the quantity should be taken from stockpile No. 1 and $10 \%$ from stockpile No. 2. For phosphate grade of 30\% P2O5, a required quantity is obtained by mixing $90 \%$ of the quantity from stockpile No. 2 and $10 \%$ from stockpile No. 3. A specified quantity of phosphate ore with grade of $29 \%$ P2O5, should be composed by blending $90.1 \%$ of the quantity from stockpile No. 3 and $9.9 \%$ from stockpile No. 4. A required quantity of phosphate ore with grade of $27 \%$ P2O5 is obtained by mixing $46.5 \%$ of the quantity from stockpile No. $4,40 \%$ from stockpile No. 5, $9.5 \%$ from stockpile No. 6 , and $4 \%$ from stockpile No. 7 . To obtain a phosphate grade of $22 \%$ $\mathrm{P} 2 \mathrm{O} 5,37.5 \%$ of the required quantity should be taken from stockpile No. 4 and $62.5 \%$ from stockpile No. 7.

For phosphate grade of $31 \% \mathrm{P}_{2} \mathrm{O}_{5}, 90 \%$ of the quantity should be taken from stockpile No. 1 and $10 \%$ from stockpile No. 2. For phosphate grade of $30 \% \mathrm{P}_{2} \mathrm{O}_{5}$, the required quantity is obtained by mixing $90 \%$ of the quantity from stockpile No. 2 and $10 \%$ from stockpile No. 3. A specified quantity of phosphate ore with grade of $29 \% \mathrm{P}_{2} \mathrm{O}_{5}$, should be composed by blending $90.1 \%$ of the quantity from stockpile No. 3 and $9.9 \%$ from stockpile No. 4 . A required quantity of phosphate ore with grade of $27 \% \mathrm{P}_{2} \mathrm{O}_{5}$ is obtained by mixing $52.5 \%$ of the quantity from stockpile No. $4,40 \%$ from stockpile No. 5 , and $7.5 \%$ from stockpile No.7. To obtain a phosphate grade of $22 \% \mathrm{P}_{2} \mathrm{O}_{5}, 27.6 \%$ of the required quantity should be taken from stockpile No. $4,15.6 \%$ from stockpile No. 6 and $56.8 \%$ from stockpile No. 7.

\section{SUMMARY AND CONCLUSIONS}

1) Optimization of blending process of phosphate ore using linear programming technique was applied according to selling price and profit.

2) Using the profit in the objective function instead of selling price gave different blending percentages and different optimal solution.

3) The optimization model is sufficient, but some improvements could be made by including the direct capital cost in the objective function.

4) Phosphate companies should choose contracts according to the results of the blending program.

5) It is recommended to use the profit in the objective function instead of selling price because the second way does not consider the costs and gives fictitious and false indications about the economics of the project.

\section{ACKNOWLEDGMENTS}

we would like to express our sincere gratitude to the Egyptian Mineral Resources Authority, El-Nasr Mining Company, and Fertilizers companies in Egypt for their data and help. 


\section{REFERENCES}

[1] Hungerländer, P. and Truden, C., (2017), "A Mixed-Integer Linear Program for the Traveling Salesman Problem with Structured Time Windows".

[2] Pannell, D., (1997), "Introduction to practical linear programming": John Wiley \& Sons.

[3] Marques, D.M. and Costa, J.F.C., (2013), "An algorithm to simulate ore grade variability in blending and homogenization piles". International Journal of Mineral Processing, p. 48-55. 120.

[4] Hillier, F.S., Boling, R., and So, K., (1986), "Toward characterizing the optimal allocation of storage space in production line systems with variable operation times", Stanford University. Department of Statistics.

[5] Elameer, Z.M., (2015), "Job planning and management in some Egyptian surface mines", in Mining and Petroleum Engineering Department, Al Azhar University: Cairo. p. 126.

[6] Hellal, F., et al., (2019), "Importance of phosphate pock application for sustaining agricultural production in Egypt". Bulletin of the National Research Centre, (1): p. 11, 43.

[7] Gupta, A., Halder, C., and Das, A., (2020), "An integrated linear programming approach in optimization of crops".

[8] Hassaan, A., (2010), "Report Economic Evaluation of U and REEs in Egyptian Phosphorite Ores". Journal of Chemical, Biological and Physical Sciences, (p. 15-20. vol. 2,

[9] USGS, (2020). "Phosphate Rock Statistics and Information", in Mineral commodity summaries, National Minerals Information Center: USA.

[10] Service, T.I.G. (2020), "Map of Egypt", [cited 2020 July].

[11] Ali, A., et al., (2018), "Optimization of blending operation for Aswan phosphate mines using linear programming". Mining of mineral deposits, (12, Iss. 4): p. 1-8.

[12] Mining, N., (2018)."Annual Production Report ".

[13] Mining, N., (2018), "Annual Export Report ", 